Г. А. Кроїк, В. І. Демура, О. М. Вінокурцева, Т. Д. Азанова-Фролова

Дніпропетровський національний університет імені Олеся Гончара

\title{
ОЦНКА ТОКСИЧНОСТІ І КЛАСУ НЕБЕЗПЕКИ ВІДВАЛЬНИХ ШАХТНИХ ПОРІД ЗАХІДНОГО ДОНБАСУ
}

\begin{abstract}
Виконані дослідження вмісту водорозчинних форм важких металів в різних типах відвальних шахтних порід Західного Донбасу. У відповідності 3 існуючими державними санітарними правилами і нормами двома методами розраховані індекси токсичності для свинцю, кадмію, цинку, кобальту, нікелю, міді. Проведена оцінка можливості застосування існуючих правил і норм при визначенні класу небезпеки твердих відходів вугледобувної промисловості.

Ключові слова: важкі метали, відходи, токсичність, порода.

Выполнены исследования содержания водорастворимых форм тяжелых металлов в разных типах отвальных шахтных пород Западного Донбаса. В соответствии с существующими государственными санитарными правилами и нормами двумя методами рассчитаны индексы токсичности для свинца, кадмия, цинка, кобальта, никеля, меди. Проведена оценка возможности применения существующих норм и правил при определении класса опасности твердых отходов угледобывающей промышленности.

Ключевые слова: тяжелые металль, отходы, токсичность, порода.

Researches of the contents of water-soluble forms of heavy metals in different types of dumping mine rocks of the Western Donbass are executed. According to existing state sanitary rules and norms two methods calculate indexes of toxicity for lead, cadmium, zinc, cobalt, nickel, copper. The estimation of an opportunity of application of existing norms and rules at definition of a class of danger of firm waste of the coal-mining industry.

Key words: heavy metals, waste, toxicity rock.
\end{abstract}

Постановка проблеми. В гірничопромислових регіонах склалася екологічна ситуація, проблема покращення якої має дві складові частини:

- убезпечення екологічної безпеки при поточному гірничопромисловому виробництві, а також при консервації і закритті гірничопромислових підприємств.

- ліквідація масштабних негативних екологічних наслідків, пов'язаних 3 накопиченням відходів за попередній період діяльності мінерально-сировинного комплексу. Враховуючи, що експлуатація багатьох великих родовищ почалася, у XIX сторіччі і вже накопичено 13 млрд м $^{3}$ породних відвалів то проблема складування і поховання таких відходів є актуальною.

Промислові відходи утворюються як при добуванні корисних копалин, так і при їх збагаченні, переробці сировинних концентратів і використанні готового продукту.

Відомо, що при добуванні корисних копалин з гірничої маси, яка надходить на поверхню йде у відходи до $93 \%$, а при подальшій їх обробці ще $5 \%$ йде у відходи. Рівень утилізації відходів складає від 1\% до 12\%. Решта накопичується у териконах, шламонакопичувачах, золовідвалах загальна площа яких перевищує 180 тис. га.

Природне середовище, як відомо має визначену стійкість до негативних екологічних навантажень. Ця стійкість залежить від величини навантаження i тривалості впливу, тобто природне середовище має потенційний запас буферності для різних природних систем. Незважаючи на це у основних гірничопромислових регіонах України за рахунок інтенсивної розробки великих родовищ всі порогові, граничні величини буферної міцності природного середовища досягли максимуму, 
а зміни екологічного стану набули важко зворотній, або незворотній характер. 3 урахуванням величезних масштабів вийнятої, переробленої та переміщеної гірничої маси розраховувати на повне або часткове відновлення і нормалізацію природного середовища неможливо. Можлива лише розробка заходів для створення нового екологічно безпечного стану. Особливість відходів гірничодобувної промисловості пов'язана 3 їх значними об'ємами і складуванням на денній поверхні на тривалий період. Такі відходи, зазвичай, займають великі площі і $є$ джерелом забруднення навколишнього середовища.

Введення в Україні нових законів пов'язаних з охороною навколишнього середовища і відповідно жорсткіший контроль природоохоронними організаціями 3 виконання вимог цих законів викликали гостру необхідність розробки нових i удосконаленні діючих природоохоронних заходів, пов'язаних з визначенням складу i властивостей відходів, ступеню їх небезпеки для навколишнього середовища $\mathrm{i}$ здоров'я людини.

Особливо жорсткий контроль стосується відходів, що містять важкі метали. Це пов'язано з тим, що навіть незначна частка важких металів щодо загального об'єму токсикантів приводить до значного забруднення територій складування відходів і погіршення їх екологічного стану. Це виявляється в антропогенному розсіюванні важких металів в біосфері, що приводить до отруєння або загрози отруєння живих організмів [1].

Вирішення цих проблем можливо лише за умов достовірної оцінки хімічного складу компонентів відходів.

Відповідно сучасним уявленням з екологічної безпеки повна та достовірна оцінка класу небезпеки відходів які вміщують важкі метали, на наш погляд, потребує додаткових, спеціальних досліджень щодо визначення не стільки валового вмісту важких металів, а в більшій мірі міграційноздатних форм металів які можуть утворювати ареали забруднення у місцях розташування відходів вугледобування. До таких форм в першу чергу можна віднести водорозчинні форми.

Мета даної роботи полягала у визначенні хімічного складу і оцінці токсичності і класу небезпеки відходів вугледобувної промисловості Західного Донбасу.

Виклад основного матеріалу. Для вирішення поставленої мети було вибрано на території Західного Донбасу досліджувану площу у руслі р. Самара. На цій площі проводились роботи з рекультивації відвалів та відсипці захисних дамб. Вибрано дві типових ділянки, які відрізняються літологічним складом та терміном відсипки. Перша ділянка - це ділянка рекультивації, верхня частина ділянки перекрита шаром чорнозему та піску. Друга ділянка - це дамба, яка складається лише $з$ відвальної шахтної породи. На ділянках розбурювали свердловини, з яких відбиралися проби порід та грунтів. У пробах визначався вміст важких металів у водорозчинній формі. Для цього готували водні витяжки зі співвідношенням фаз дистильована вода : порода (1:5) У водних витяжках визначали вміст важких металів методом атомно-абсорбційної спектрометрії. Результати аналізів наведені на рис. $1,2$.

Відходи вугледобування у Західному Донбасі представлені відвальними шахтними породами та породами зі збагачувальної фабрики. Вміст металів в породах знаходиться в діапазоні від 0,01 до 8,00 мк/кг. Найбільша концентрація важких металів в породах відповідає вмісту цинку та нікелю. Найменша кількість металів присутніх в породах відповідає кадмію, міді. 


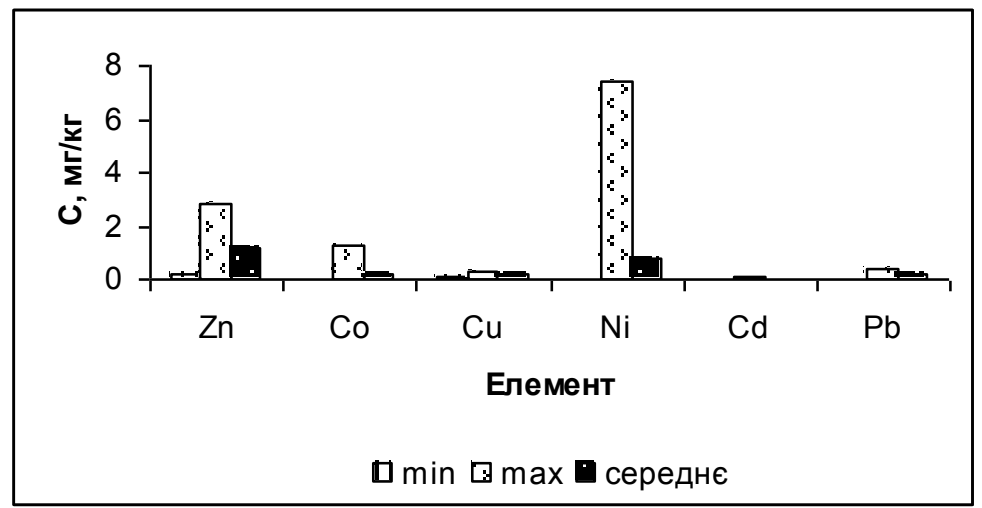

Рис. 1 Вміст важких металів у відвальних шахтних породах Західного Донбасу (I ділянка)

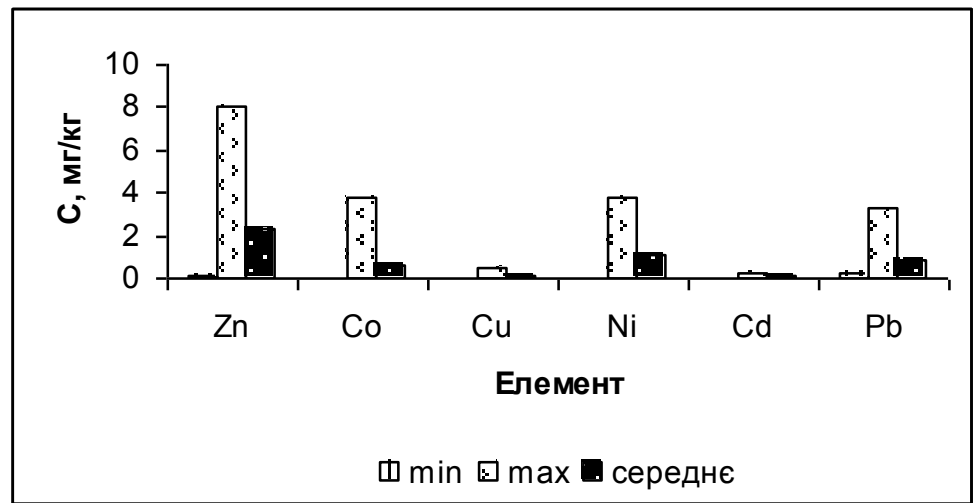

Рис. 2 Вміст важких металів у відвальних шахтних породах Західного Донбасу (II ділянка)

Таким чином породи вміщують важкі метали I класу небезпеки ( $\mathrm{Pb}, \mathrm{Cd}, \mathrm{Zn})$ та II класу небезпеки $(\mathrm{Cu}, \mathrm{Ni}, \mathrm{Co})$. Отримані результати лягли в основу визначення класу небезпеки відходів вугледобування.

Офіційно затвердженою методикою визначення класу небезпеки відходів $€$ Державні Санітарні правила та норми [2]. Ці правила встановлюють гігієнічні вимоги і критерії щодо визначення класу небезпеки відходів за ступенем їх токсичності, вони дозволяють встановити межі шкідливого впливу токсичних відходів безпосередньо на середовище життя і відповідно попередити можливість погіршення здоров'я населення. Ці правила $\epsilon$ обов'язковими для виконання органами державної виконавчої влади, місцевого та регіонального самоврядування, суб'єктами права власності та суб'єктами у сфері поводження з відходами (ст. 25. Закон України „Про забезпечення санітарного та епідемічного благополуччя населення).

Згідно 3 [2] метод використовується в тому разі, якщо встановлено або відомо якісний і кількісний склад відходів та в літературних джерелах є необхідні відомості для визначення показників небезпеки компонентів відходу.

Визначали клас небезпеки відходів за формулами 1, 2.

$$
K_{i}=\frac{\lg \left(L D_{50}\right)_{i}}{\left(s+0,1 F+C_{\hat{a}}\right)_{i}}
$$


де $K_{\mathrm{i}}$ - індекс токсичності кожного хімічного інгредієнту, що входить до складу відходів, величину $\mathrm{K}_{\mathrm{i}}$ округлюють до першого знаку після коми;

$\lg \left(\mathrm{LD}_{50}\right)$ - логарифм середньої смертельної дози хімічного інгредієнту при введені в шлунок, $\left(\mathrm{LD}_{50}\right)$ знаходять за довідниками;

$\mathrm{s}$ - коефіцієнт, який відображає розчинність хімічного інгредієнта у воді за допомогою довідника знаходять розчинність хімічного інгредієнта у воді в грамах на 100 г води при температурі не вище $25^{\circ} \mathrm{C}$, цю величину ділять на 100 i отримують безрозмірний коефіцієнт $\mathrm{s}$, який в більшості випадків знаходяться в інтервалі від 0 до 1 ;

$\mathrm{F}$ - коефіцієнт леткості хімічного інгредієнта знаходять за допомогою довідників; він знаходяться в інтервалі від 0 до 1 ;

$\mathrm{C}_{\text {в }}$ - кількість даного інгредієнта в загальній масі відходу, т/т;

i - порядковий номер конкретного інгредієнта.

Після розрахунку К для окремих інгредієнтів відходу, обирають не більше 3 , але не менше 2 ведучих, які мають найменші $\mathrm{K}_{\mathrm{i}}$, при цьому $\mathrm{K}_{1}<\mathrm{K}_{2}<\mathrm{K}_{3}$, крім того повинна виконуватись умова $2 \mathrm{~K}_{1}>\mathrm{K}_{3}$

$$
K_{\Sigma}=\frac{1}{n^{2}} \sum_{i=1}^{n} K_{i}, \mathrm{n} \leq 3
$$

де $K_{\Sigma}$ - сумарний індекс токсичності. Цей коефіцієнт обчислюється за допомогою двох або трьох вибраних індексів токсичності, після чого визначають клас небезпеки та ступінь токсичності відходу (табл. 1).

Класифікація небезпеки відходів за LD

\begin{tabular}{|l|c|l|}
\hline \multicolumn{1}{|c|}{$\begin{array}{c}\text { Величина } \mathrm{K}_{\Sigma} \text {, отримана на } \\
\text { основі LD }\end{array}$} & Клас небезпеки & \multicolumn{1}{|c|}{ Ступінь токсичності } \\
\hline Менше 1,3 & I & Надзвичайно небезпечні \\
\hline Від 1,3 до 3,3 & II & Високо небезпечні \\
\hline Від 3,4 до 10 & III & Помірно небезпечні \\
\hline Від 10 і більше & IV & Мало небезпечні \\
\hline
\end{tabular}

Враховуючи те, що відходи які досліджувались в данній роботі не мають впроваджених схем утилізації, знешкодження чи оброблення i складування їх проводиться на денній поверхні, а термін зберігання досягає $10-30$ років, за цих умов відбувається безпосередній контакт відходів з об'єктами довкілля.Тому для визначення класу небезпеки цих відходів використовуються правила СанПіНу 3 урахуванням ГДК важких металів у грунті згідно з формулою:

$$
K_{i}=\frac{\tilde{A} \ddot{A} \hat{E}_{3}}{\left(s+0,1 F+C_{\hat{a}}\right)_{i}},
$$

де ГДК - гранично допустима концентрація токсичної хімічної речовини у грунті, що міститься у відході;

$\mathrm{K}_{\mathrm{i}}, \mathrm{s}, \mathrm{C}_{\mathrm{B}}, \mathrm{F}, \mathrm{i}$ - ті ж самі показники, що у формулі 1.

Розрахунок окремих індексів токсичності виконували як і у попередньому разі за формулою 2.

Класифікація небезпеки відходів за величино ГДК хімічних речовин у грунті має дещо інший вигляд (табл. 2). 
Класифікація небезпеки відходів за ГДК хімічних речовин у грунті.

\begin{tabular}{|l|c|l|}
\hline \multicolumn{1}{|c|}{$\begin{array}{c}\text { Величина К } \\
\text { основі ГДК у уримана на }\end{array}$} & Клас небезпеки & \multicolumn{1}{|c|}{ Ступінь токсичності } \\
\hline Менше 2 & I & Надзвичайно небезпечні \\
\hline Від 2 до 16 & II & Високо небезпечні \\
\hline Від 16,1 до 30 & III & Помірно небезпечні \\
\hline Від 30,1 і більше & IV & Мало небезпечні \\
\hline
\end{tabular}

Експериментально встановлено що важкі метали знаходяться у шахтних породах Західного Донбасу у вигляді сульфатних сполук, тому для розрахунку індексів токсичності використовували розчинність сульфатів. Визначення індексів токсичності проводилося за середніми значеннями концентрацій важких металів. За величиною індексу токсичності, яка визначена за показником $\mathrm{LD}_{50}$, досліджувані метали можна представити у вигляді ряду:

$\mathrm{Pb}>\mathrm{Cu}>\mathrm{Co}>\mathrm{Ni}>\mathrm{Zn}>\mathrm{Cd}$

Індекси токсичності I та II ділянок наведені в таблиці 3

Найбільші значення індексів токсичності відповідають сполукам хрому, свинцю, найменші - сполукам цинку, нікелю, кадмію. Сумарний індекс токсичності для відходів розташованих на I та II ділянках складає 0,93, що відповідає надзвичайно небезпечним (I клас небезпеки).

Табличя 3

Індекси токсичності I та II ділянок

\begin{tabular}{|l|c|c|}
\hline \multirow{2}{*}{ Сполуки металів } & \multicolumn{2}{|c|}{ Індекси токсичності } \\
\cline { 2 - 3 } & розраховані за $\mathrm{LD}_{50}$ & розраховані за ГДК \\
\hline $\mathrm{ZnSO}_{4}$ & 2,24 & 13,94 \\
\hline $\mathrm{CoSO}_{4}$ & 6,69 & 12,72 \\
\hline $\mathrm{CuSO}_{4}$ & 7,95 & 14,63 \\
\hline $\mathrm{NiSO}_{4}$ & 3,91 & 10,42 \\
\hline $\mathrm{CdSO}_{4}$ & 2,19 & 0,92 \\
\hline $\mathrm{PbSO}_{4}$ & 54239,5 & 130861,5 \\
\hline
\end{tabular}

За величиною індексу токсичності, яка визначена з урахуванням показника ГДК, досліджувані метали можна розташувати у вигляді ряду:

$\mathrm{Pb}>\mathrm{Cu}>\mathrm{Zn}>\mathrm{Co}>\mathrm{Ni}>\mathrm{Cd}$.

Найбільші значення індексів токсичності відповідають сполукам хрому і свинцю. Індекси токсичності сполук цинку, кобальту, нікелю, міді знаходяться в діапазоні від 10 до 14. Сумарний індекс токсичності для відходів розташованих на I та II ділянках складає 2,8, що відповідає високо небезпечним (II клас небезпеки)

Висновки. Таким чином, проведені дослідження дозволили оцінити наявність важких металів I та II класу небезпеки у відходах вугледобування Західного Донбасу. Отримані результати оцінки токсичності відходів різними способами дозволяє їх віднести до різних класів небезпеки. Це можна пояснити деякими обмеженнями існуючої методики. Вони пов'язані 3 не врахуванням формоутворювання та ролі різних форм в санітарно - гігієнічному нормуванні. Удосконалення існуючого методу можливо з використанням геохімічного підходу.

\section{Бібліографічні посилання}

1. Гончарук В. В. Физико-химические аспекты проблемы загрязнения почв и гидросферы тяжелыми металлами / В. В. Гончарук, Н.М. Соболева, А. А. Носонович // Химия в интересах устойчивого развития. - Новосибирск, 2003. - Т. 11, №6. - С 795-813

2. ДСанПіН 2.2.7.029-99 Гігієнічні вимоги щодо поводження 3 промисловими відходами та визначення їх класу небезпеки для здоров'я населення Надійшла до редколегії 25.04.11 
